\title{
THE LITTLE SCREECH OWL.
}

\author{
†Bubo Asio, Linn.
}

PLATE XL.-Adult and Young.

This Owl, although found in the Southern States, is there very rare. During a long residence in Louisiana, I have not met with more than two individuals. On advancing towards the confluence of the Ohio and Mississippi, we find them becoming rather more numerous; above the Falls of the former, they increase in number; and as the traveller advances towards the sources of that noble river, their mournful notes are heard in every quarter during mild and serene nights. In Virginia, Maryland, and all the Eastern Districts, the bird is plentiful, particularly during the autumnal and winter months, and is there well known under the name of the Screech Owl.

You are presented, kind reader, with three figures of this species, the better to shew you the differences which exist between the young and the full-grown bird. The contrast of colouring in these different stages I have thought it necessary to exhibit, as the Red Owl of Wilson and other naturalists is merely the young of the bird called by the same authors the Mottled Owl, and which, in fact, is the adult of the species under consideration. The error committed by the author of the "American Ornithology," for many years misled all subsequent students of nature; and the specific identity of the two birds which he had described as distinct under the above names, was first publicly maintained by my friend Charles Lucian Bonaparte, although the fact was long before known to many individuals with whom I am acquainted, as well as to myself.

The flight of the Mottled Owl is smooth, rapid, protracted and noiseless. It rises at times above the top branches of the highest of our forest trees, whilst in pursuit of large beetles, and at other times sails low and swiftly over the fields, or through the woods, in search of small birds, field-mice, moles or wood-rats, from which it chiefly derives its subsistence. Sometimes on alighting, which it does plumply, the Mottled $\mathrm{O}$ wl immediately bends its body, turns its head to look behind it, performs a curious nod, utters its notes, then shakes and plumes itself, and resumes its flight, in search of prey. It now and then, while on wing, produces a clicking sound with its mandibles, but more frequently when perched near its mate or young. This I have thought is done by the bird to manifest its courage, and let the hearer know that it is not to be meddled with, although few birds of prey are more 
gentle when seized, as it will suffer a person to touch its feathers and caress it, without attempting to bite or strike with its talons, unless at rare intervals. I carried one of the young birds represented in the Plate, in my coat pocket, from Philadelphia to New York, travelling alternately by water and by land. It remained generally quiet, fed from the hand, and never attempted to escape.

The notes of this Owl are uttered in a tremulous, doleful manner, and somewhat resemble the chattering of the teeth of a person under the influence of extreme cold, although much louder. They are heard at a distance of several hundred yards, and by some people are thought to be of ominous import.

The little fellow is generally found about farm-houses, orchards, and gardens. It alights on the roof, the fence or the garden gate, and utters its mournful ditty at intervals for hours at a time, as if it were in a state of great suffering, although this is far from being the case, the song of all birds being an indication of content and happiness. In a state of confinement, it continues to utter its notes with as much satisfaction as if at liberty. They are chiefly heard during the latter part of winter, that being the season of love, when the male bird is particularly attentive to the fair one which excites his tender emotions, and around which he flies and struts much in the manner of the Common Pigeon, adding numerous nods and bows, the sight of which is very amusing.

The nest is placed in the bottom of the hollow trunk of a tree, often not at a greater height than six or seven feet from the ground, at other times so high as from thirty to forty feet. It is composed of a few grasses and feathers. The eggs are four or five, of a nearly globular form, and pure white colour. If not disturbed, this species lays only one set of eggs in the season. The young remain in the nest until they are able to fly. At first they are covered with a downy substance of a dull yellowish-white. By the middle of August they are fully feathered, and are then generally of the colour exhibited in the Plate, although considerable difference exists between individuals, as I have seen some of a deep chocolate colour, and others nearly black. The feathers change their colours as the pairing season advances, and in the first spring the bird is in its perfect dress.

The Mottled $\mathrm{Owl}$ rests or spends the day either in a hole of some decayed tree, or in the thickest part of the evergreens which are found so abundantly in the country, to which it usually resorts during the breeding season as well as in the depth of winter.

The branch on which you see three individuals of this species, an adult bird and two young ones, is that of the Jersey Pine (Pinus inops), a tree of moderate height and diameter, and of a scrubby appearance. The stem is 
generally crooked, and the wood is not considered of great utility. It grows in large groves in the state from which it has derived its name, and is now mostly used for fuel on board our steam-vessels. The Mottled $\mathrm{Owl}$ is often observed perched on its branches.

Mottled Owl, Strix nævia, Wils. Amer. Orn., vol, iii. p. 16. Adult.

RED OwL, Strix Asio, Wils. Amer. Orn., vol. v. p. 83. Young.

Mottled and Red Owh, Strix .Asio, Nutt. Man., vol. i. p. 120.

Little Screech Owl, Strix Asio, Aud. Orn. Biog., vol. i. p. 486; vol. v. p. 392.

Adult with the upper parts pale brown, spotted and dotted with brownishblack; a pale grey line from the base of the upper mandible over each eye; quills light brownish-grey, barred with brownish-black, their coverts dark brown, secondary coverts with the tip white; throat yellowish-grey, lower parts light grey, patched and sprinkled with brownish-black; tail-feathers tinged with red. Young with the upper parts light brownish-red, each feather with a central blackish-brown line; tail and quills barred with dull brown; a line over the eye, and the tips of the secondary coverts reddishwhite; breast and sides light yellowish-grey, spotted and lined with brownishblack and bright reddish-brown, the rest of the lower parts yellowish-grey, the tarsal feathers pale yellowish-red.

Male, 10, 22. Female, 10, 23.

VoL. I. 


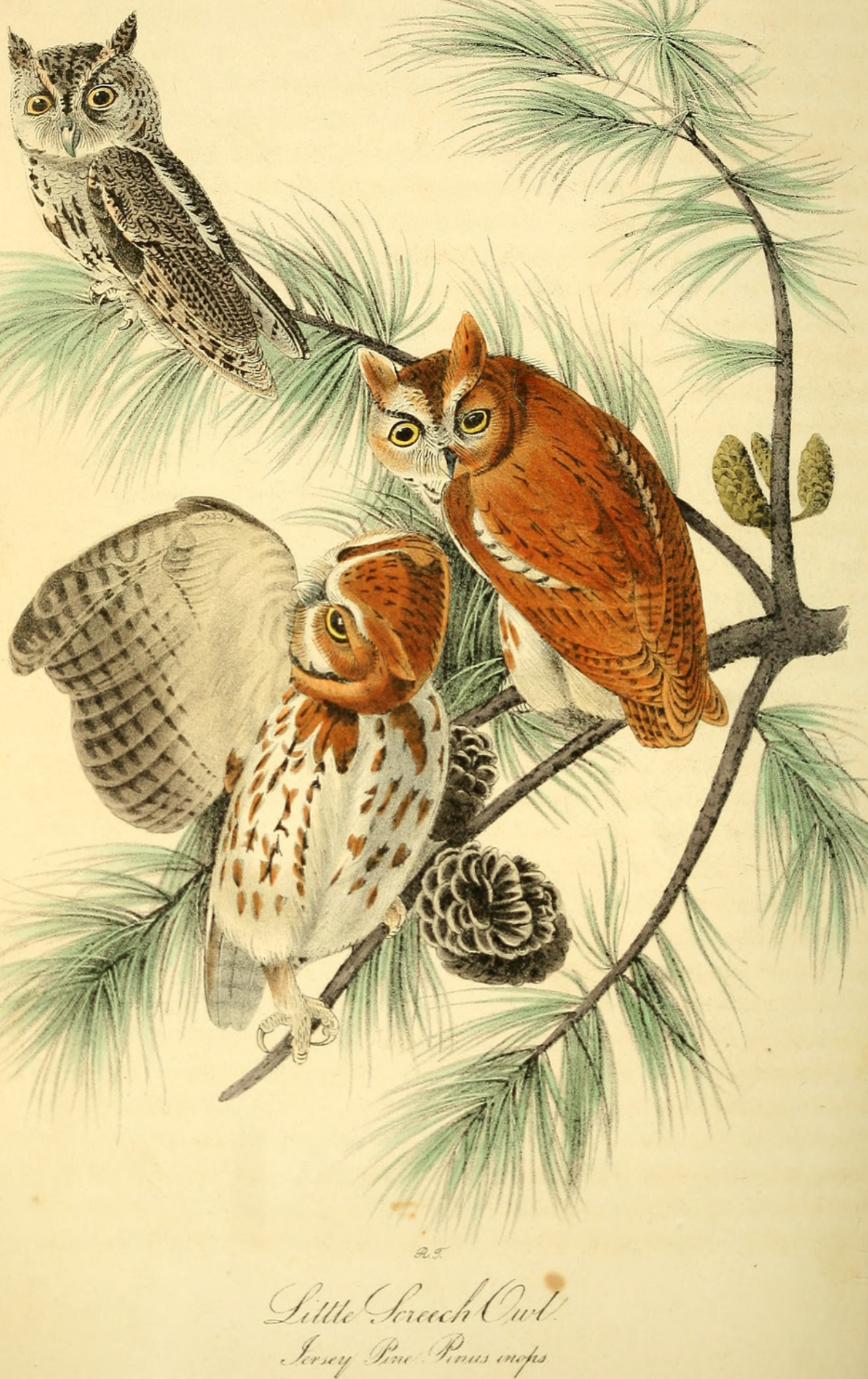




\section{$2 \mathrm{BHL}$ Biodiversity Heritage Library}

Audubon, John James. 1840. "The Little Screech Owl, Buro asio, Linn. [PI. 40]." The birds of America : from drawings made in the United States and their territories 1, 147-149. https://doi.org/10.5962/p.319153.

View This Item Online: https://www.biodiversitylibrary.org/item/124833

DOI: https://doi.org/10.5962/p.319153

Permalink: https://www.biodiversitylibrary.org/partpdf/319153

\section{Holding Institution}

Smithsonian Libraries

\section{Sponsored by}

Biodiversity Heritage Library

\section{Copyright \& Reuse}

Copyright Status: NOT_IN_COPYRIGHT

This document was created from content at the Biodiversity Heritage Library, the world's largest open access digital library for biodiversity literature and archives. Visit BHL at https://www.biodiversitylibrary.org. 